\title{
Globalization-In the Name of Which Freedom?
}

\author{
Jeffrey D. Sachs ${ }^{1}$
}

Published online: 31 March 2017

(C) Springer International Publishing 2017

\begin{abstract}
I consider four waves of globalization. The first is Commercial Capitalism (15001800 ), following the voyages of Columbus and Da Gama. The second is Industrial Capitalism (1800-1950), following the industrial revolution led by the steam engine and mechanization. The third is the Era of Convergence (1950-Present), following the end of the European empires after World War II. The fourth is the New Globalization (Present-2100) marked by three decisive trends: the relative rise of Asia, the Information Revolution, and the stark crises of Planetary Boundaries. I argue that modern globalization must urgently establish a new moral basis and the cultivation of virtues in order to achieve Sustainable Development.
\end{abstract}

Keywords Globalization $\cdot$ Convergence $\cdot$ Sustainable development $\cdot$ Planetary boundaries

\section{Introduction}

Thank you very much for the high honor of the Lifetime Achievement Award of the Humanistic Management Network. I am deeply grateful for the beautiful plaque engraved with Leonardo da Vinci's Vitruvian Man. We are about 500 years from Da Vinci's time, a good starting point for my comments today. Da Vinci produced the Vitruvian Man in 1490. Two years later Christopher Columbus sailed to the new world. And 6 years after that, in 1498, Vasco da Gama sailed from Europe to Asia and back. Globalization had begun, and the world would never be the same.

\section{Early Capitalism and Globalization}

I have been studying Thomas More's Utopia on the 500th anniversary of the publication of that great work in 1516. It is no accident that Utopia followed quickly upon the momentous

Jeffrey D. Sachs

sachs@ei.columbia.edu

1 Center for Sustainable Development, Columbia University, New York, USA 
discoveries of da Vinci, Columbus, and da Gama. Man's intellectual horizons were fundamentally altered, and expanded by the discovery of the vastness of the world, and the changes wrought by early globalization. And the new printing press meant that the new speculations could reach thousands of readers across Europe and thereby promote further breakthroughs in understanding.

Indeed, I might hazard the judgement that the 1510's was the single greatest decade of intellectual speculation in all of modern history. In 1513, Copernicus produced the first draft of the Heliocentric Universe. In 1514, Machiavelli wrote The Prince. In 1516, More published Utopia. And in 1517, Luther published his 95 Theses, launching the Reformation. That's not at all bad for 4 years of book publication! And one could add in the outpourings of Bramante, Michelangelo, Rafael, Titian, and other masters producing their eternal masterpieces in these years.

Adam Smith, writing in the Wealth of Nations in 1776, had this to say about the years just before 1500. "The discovery of America, and that of a passage to the East Indies by the Cape of Good Hope, are the two greatest and most important events recorded in the history of mankind." That is a very strong statement, and also quite a remarkable statement. Most importantly, it stands the test of time.

Smith continues his reasoning about the two momentous discoveries as follows:

Their consequences have already been very great; but, in the short period of between two and three centuries which have elapsed since these discoveries were made, it is impossible that the whole extent of their consequences can have been seen. What benefits, or what misfortunes to mankind may hereafter result from those great events, no human wisdom can foresee. By uniting, in some measure, the most distant parts of the world, by enabling them to relieve one another's wants, to increase one another's enjoyments, and to encourage one another's industry, their general tendency would seem to be beneficial.

Yet Smith goes on as follows:

To the natives, however, both of the East and West Indies, all the commercial benefits which can have resulted from those events have been sunk and lost in the dreadful misfortunes which they have occasioned. These misfortunes, however, seem to have arisen rather from accident than from anything in the nature of those events themselves. At the particular time when these discoveries were made, the superiority of force happened to be so great on the side of the Europeans that they were enabled to commit with impunity every sort of injustice in those remote countries. Hereafter, perhaps, the natives of those countries may grow stronger, or those of Europe may grow weaker, and the inhabitants of all the different quarters of the world may arrive at that equality of courage and force which, by inspiring mutual fear, can alone overawe the injustice of independent nations into some sort of respect for the rights of one another. But nothing seems more likely to establish this equality of force than that mutual communication of knowledge and of all sorts of improvements which an extensive commerce from all countries to all countries naturally, or rather necessarily, carries along with it.” (Smith, Wealth of Nations, Book IV)

If I had to choose one scrap of wisdom about human history, I would choose this one from The Wealth of Nations. Everything about Smith's statement is wonderful. First, Smith recognized the fundamentally transformative nature of the globalization that began with the voyages of 1492 and 1498. Second, Smith recognized that globalization would have potentially hugely beneficial implications, by enabling each part of the world "to relieve one another's wants." This is of course is Smith's basic theory of the gains from trade. Yet third, Smith recognized that the gains were in fact not shared equally, and that in fact while Europe gained massively, 
the native inhabitants of the East and West Indies actually suffered horrendously from the impunity and abuses of the more powerful Europeans. (Smith was unaware that the native inhabitants also suffered from the pathogens brought by the Europeans, as it was only one century after Smith that Pasteur and Koch developed the germ theory of disease.)

It is a mark of Smith's greatness, as well as the greatness of the Scottish Enlightenment overall, that Smith bemoaned the inequality of the exchange. Smith was Scottish, but his outlook was global. That's why Smith looked forward to the day when the native inhabitants would acquire sufficient power to rebalance the books, and achieve an "equality of courage and force" with the Europeans. How would this happen, according to Smith? Through trade itself, which would lead to "the mutual communication of knowledge and of all sorts of improvements" that trade brings about.

My theme today is that we are living in the "Smith moment" in our own generation. We are living at the moment, after several waves of globalization that I will soon discuss, in which an equality of courage and force across the world is finally taking hold. This is seen most vividly in the recent economic rise of the great powers of Asia, including China and India. These Asian giants are no longer under the domineering sway of European or American power.

We must ask ourselves about the kind of world that will emerge in a world of more disbursed power. Smith, interestingly, asserts a balance-of-power view, one that modern International Relations (IR) specialists would label "realism." Smith believed that an equality of force would inspire "mutual fear," which "can alone overawe the injustice of independent nations." Smith's is the logic of realism, of achieving global peace through the balance of power among independent nations.

We should also look to another great thinker who wrote on the same subject just 17 years after Smith. Immanuel Kant had different hopes for geopolitics, which he called "perpetual peace." Kant believed that when the nations of the world assumed a "republican" form of government, meaning in Kant's sense a state bound by the rule of law, then the nations would forswear violence in the interests of commerce. Kant's theory of perpetual peace would be called a form of Idealism or Institutionalism by today's IR specialists.

Before returning to the questions of how to achieve global peace in our generation, I will take us on a very brief tour through the phases of globalization that have brought us to today's new equality of courage and force.

\section{Commercial Capitalism, 1500-1800}

Columbus and da Gama set off a three-century process that was marked by Europe's growing dominance of global sea-based commerce. Europeans colonized the Americas (and later Australia) at horrific costs to the native inhabitants. They incorporated these new lands and parts of coastal Asia and North Africa into a global production system based on slave production in the colonies and global-scale sea-borne trade. As their economic and military power rose, the European states became not only colonizers but imperial powers across the Americas, North Africa and Asia. Interestingly, they did not succeed in colonizing subSaharan Africa until the second half of the 19th century, largely because malaria was a barrier to European colonization and imperial rule until the Europeans discovered and mass produced the anti-malarial quinine (extracted from the bark of the South American cinchona tree).

By 1800, there was a capitalist global economy run by the Europeans, illustrated by the map of empires in Fig. 1.

This was a world already defined by intense global commerce in which several new global industries had developed: cotton for textiles; sugar and tobacco grown by slaves in the 


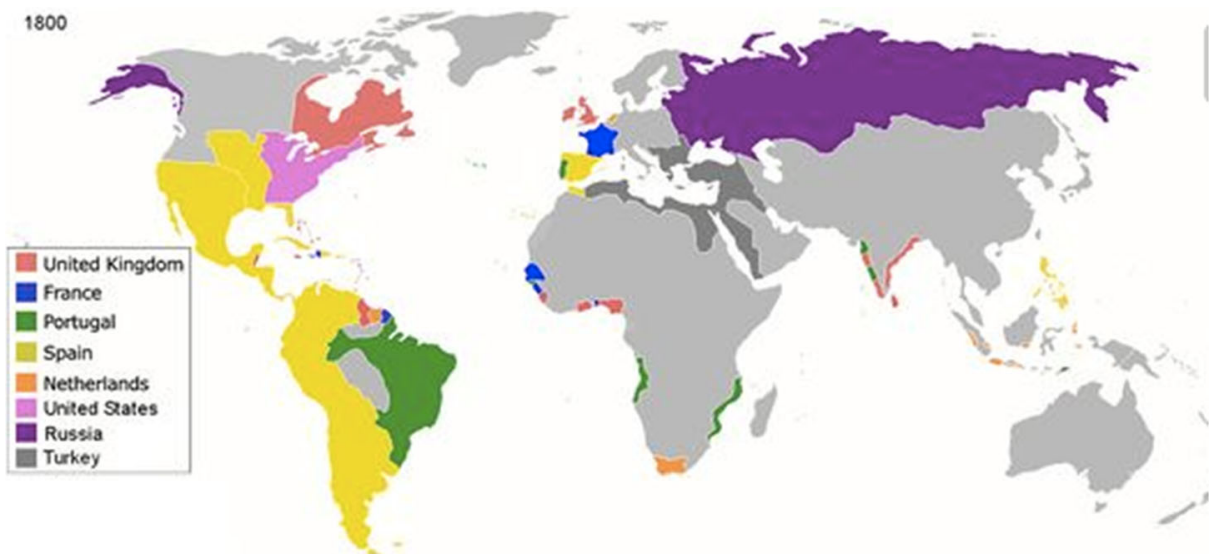

Fig. 1 World empires as of 1800

Americas; coffee grown in Asia and Africa. And of course there was the insatiable quest for gold and silver from the mines of the Americas and later southeast Asia. The major commodity trade flows are shown in Fig. 2.

I would highlight a few of the key characteristics of this first phase of global capitalism, dating roughly from 1500 to 1800 . First, it produced a truly global economy. Second, it was incredibly dynamic - the very hallmark of capitalism. It is remarkably dynamic. It was driven by the lust for profits, visions of glory, and yearnings for great wealth. It produced outcomes that are unimaginable in scale and scope. We should reflect that before the phone, the radio, the telegraph, indeed any form of rapid communications, multinational companies and European imperial governments were straddling the world in remarkable feats of scale, scope, and sheer logistics.

Third, of course, this world of commercial capitalism was indescribably brutal. The Europeans were not just colonizers; they were mass murderers and mass enslavers. We have

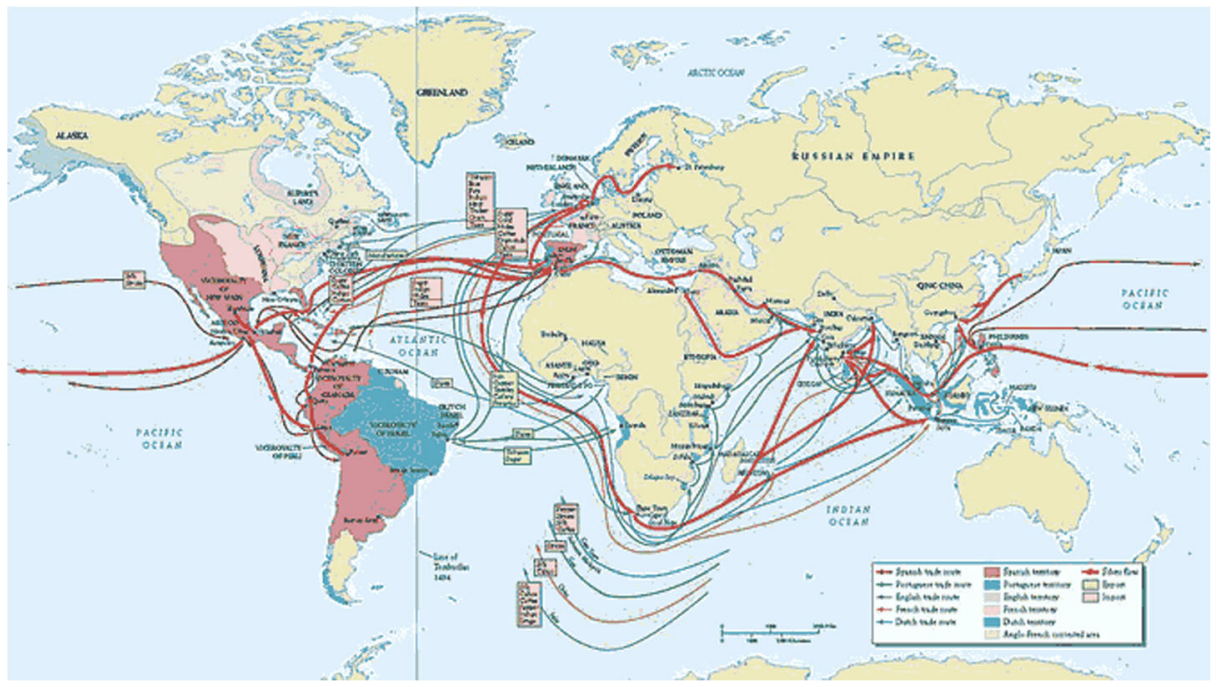

Fig. 2 Trade flows by empire and commodities (Cotton, sugar, coffee, gold and slave economy) 
smoothed over this brutality in our books and teachings, but it is plain to see. Murder, genocide, ethnic cleansing, and slavery, were all foundational parts of early capitalism, and typically carried out in the name of bringing "civilization" to the natives.

There is a fourth point as well. Commercial capitalism was mercantilist, meaning that it emerged as an alliance of companies (like the East India Company) and government. There was little that was "free market" about commercial capitalism during 1500-1800. The European navies protected their merchant fleets. Business and government colluded at every turn. That pattern is still with us today, despite the introductory economics textbooks written to the contrary.

\section{Industrial Capitalism, 1800-1950}

The second wave of globalization began around the very same moment that Adam Smith published the Wealth of Nations. The year 1776 was not only the year of Smith's magnum opus, and of the American Declaration of Independence, but also of another world-changing event, the patenting of James Watt's steam engine. Figure 3. We know the consequences of the steam engine, but are still waiting to see how America's Declaration of Independence ultimately plays out.

Watt's engine was perhaps the single most important technological breakthrough since agriculture, or at least a rival of the horse-drawn plow, the sailboat and windmill, and the printing press. The steam engine allowed humanity to break free of what economic historians now call the "organic economy." The organic economy means an economy in which the primary energy sources are limited to human brawn, animal traction, wind power for sails, and some water wheels and windmills to power industry in a few choice locations. Economic historians like E. H. Wrigley have cogently explained that an organic economy can hardly rise above subsistence. The steam engine allowed the breakthrough beyond subsistence, by harnessing the vast energy stored in fossil fuels.

Figure 4 offers a graphical depiction of what this breakthrough meant for the world economy. It shows the estimate of world output produced by the late economic historian Angus Maddison. We see the momentous change around 1800. We enter what the inventor of modern development economics, Simon Kuznets, called "Modern Economic Growth." Before the steam engine, there was stasis; afterwards, economic growth.

Population followed the same trend. The Industrial Revolution made possible an agricultural revolution as well. In the 19th century, for example, guano from the west coast of South America could be brought by steamship to Europe to serve as a large-scale chemical fertilizer. Food production soared. And with rising food production and farm production, the world

Fig. 3 James Watt's engine

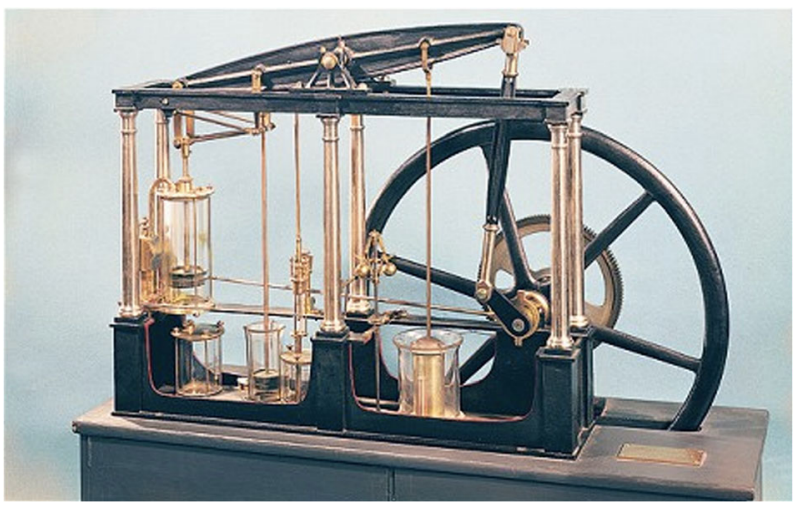


Fig. 4 World output per person

World Output Per Person

(1990 International Dollars)

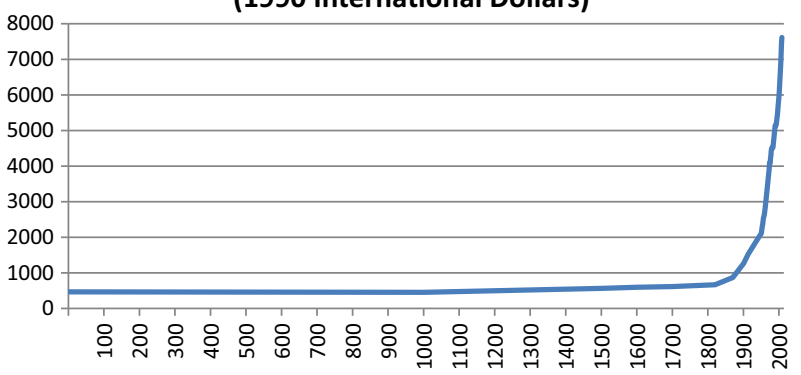

population also soared, as seen in Fig. 5. The world population had fluctuated between 200 million to 500 million until around 1700; the ups and downs were due to epidemic diseases and localized climate changes. Then, food production exploded as a result of industrialization and the science that came along with it.

The Industrial Age transformed the world and created a world industrial economy. The industrial economy was characterized by what is now called "endogenous growth," meaning that one revolution of technology led to the next through a kind of chain reaction. So, what started with the steam engine becomes the railway era; then Faraday's discoveries of electromagnetism lead to the electric dynamo and the start of electrification in the second half of the 19th century. The inventions of Daimler and Benz give the world the internal combustion engine and the automobile age. On and on it has gone, until today we are the beneficiaries of the information revolution, in which every day a new breakthrough - in my view is as consequential as any of the breakthroughs of the past-pours forth.

Our capacity to manage, manipulate, store, and transmit data will completely transform the world economy once again. We see this happening before our eyes. Just yesterday, DeepMind of Google announced a new breakthrough in artificial intelligence with a neural network now separated from the computer memory, which allows for a massive expansion in artificial intelligence, computational power, and machine learning. Discoveries like these are coming every day.

Of course, what endogenous growth meant beginning around 1800 was persistent economic growth. But another notable fact from 1800 until today has been differential economic growth across the world map. At the beginning of the new economic era, one country and one country

Fig. 5 12,000 years of population growth

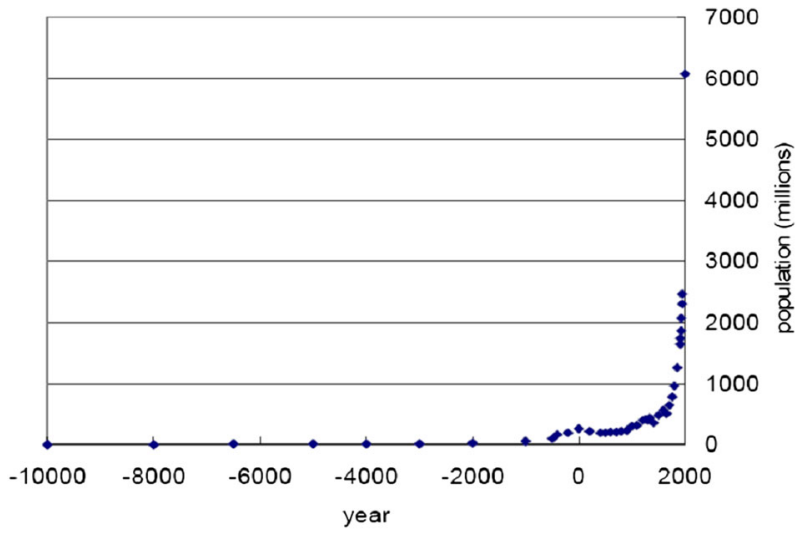


alone had an Industrial Revolution - and that was Britain. Then, the Industrial Revolution started to spread. It spread next to next-door, to France, and then in the 1840 s, to Germany and to the United States, and from then to more and more parts of the world. But, one part of the world, Western Europe and the United States (also known as the North Atlantic) achieved early economic growth that was sustained for two centuries. What had been established as the Western World between 1500 and 1800, became a dominant Western World in the 19th and 20th centuries. The economic dominance of the Western World (more accurately, the North Atlantic regions of Europe and North America, plus Australia, New Zealand, and Japan) peaked around 1950, at which time the Western predominance very slowly began to subside as Asia countries began to achieve rapid economic growth.

Some parts of the world experienced almost no modern economic growth for a century and a half after the start of industrialization. Africa is the main region that remained in this category until recently (the red curve on the bottom in Fig. 6). Explaining the differential growth paths of GDP per capita shown in Fig. 6 (based on Maddison's data) is, in essence, the job of economic development theory and history - to understand why different regions of the world experience vastly differential growth.

One interesting relationship that I have been pursuing with my colleague Gordon McCord is geography's effect on the diffusion of growth. Figure 7 relates two variables. On the horizontal access is the distance from London of the capital cities of Europe. On the vertical access is the calendar year in which each European country first surpassed the threshold of \$2000 per capita income (measured in 1990 prices by Maddison). We see an upward-sloping scatter plot. The farther is the country from the U.K. (measured as the distance to London), the later did the country pass the threshold of $\$ 2000$ per capita. In other words, industrialization started in England. Then it spread nearby to Belgium, Netherlands, and France. And then later still to Switzerland, Germany, Scandinavia, etc. Economic growth moved like a spreading wave over Europe, from West to East, North to South.

If we look at global diffusion of modern economic growth, we find the picture in Fig. 8. Economic growth came first to Western Europe, the US and Australia. Then it spread to

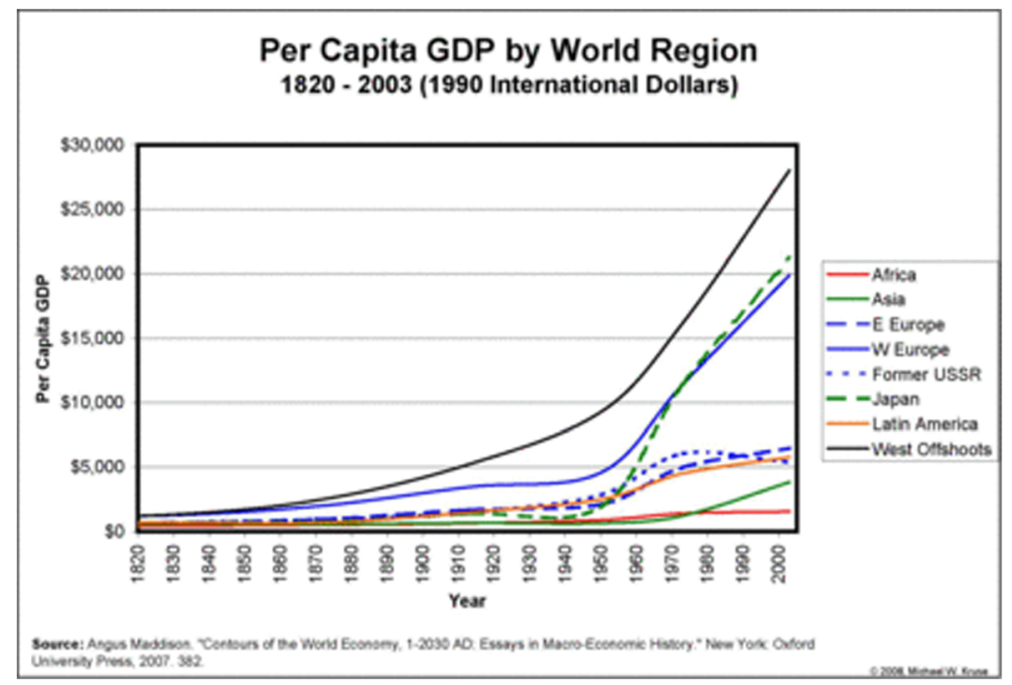

Fig. 6 Differential growth by region 
Fig. 7 Distance from London and the year of reaching \$2000 in GDP per capita

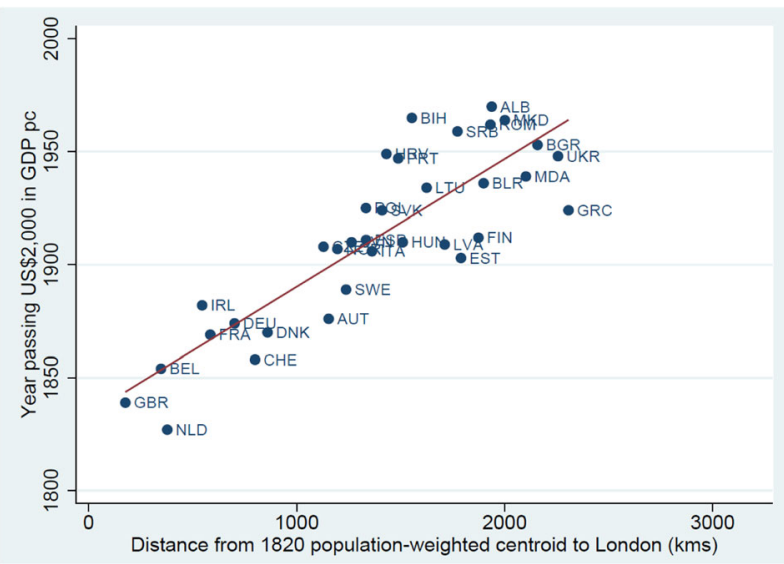

Central and Eastern Europe, and the Southern Cone of Latin America. It spread next to Russia and other parts of the former Soviet Union. After World War II, many parts of Asia finally reached $\$ 2000$ per capita. Africa is the laggard region. Until today, much of tropical subSaharan Africa remains under the $\$ 2000$ per capita standard (measured, as per Maddison, in 1990 dollars).

\section{Year (or Projected Year) Passing \$2000 Income}

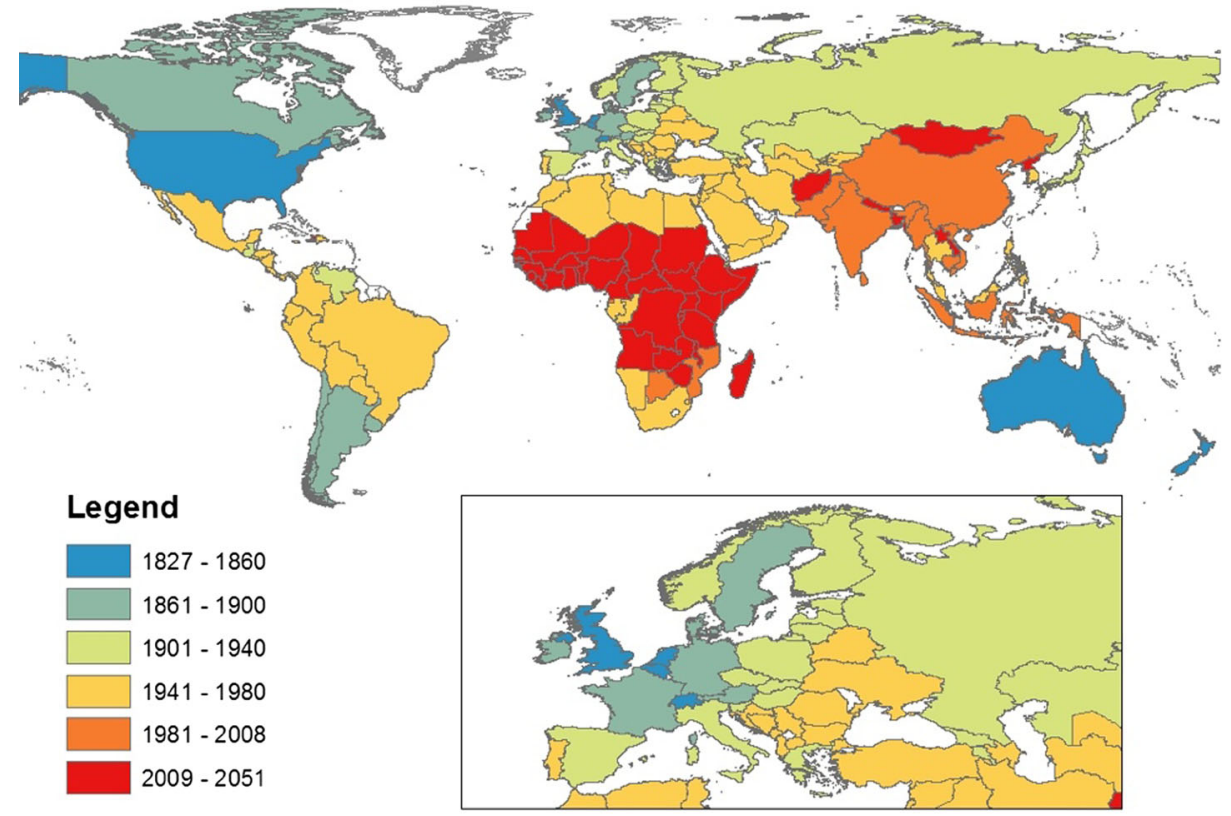

Note that the United States and Australia had very high per-capita incomes very early on because they had all the land that they could take from the indigenous populations. As soon as the indigenous populations were brutally pushed aside, it was an "endless frontier," and that meant very high income

Fig. 8 Year (or projected year) passing \$2000 income 
Europe's disproportionate industrial might also led to Europe's disproportionate military might on the geopolitical scale. As the world's only industrial powers, Western European powers in the 19th century began to conquer overseas societies in Asia and Africa, and to build empires in these regions. By 1900, much of the world, including almost all of Africa and much of Asia, was ruled by European empires. The world's empires as of the year 1914 are shown in Fig. 9.

One of the predominant behavioral principles of European imperialism was: "Do not educate the natives. That could be dangerous for your political control." Yet without even a modicum of education in the imperial possessions, there could be no long-term economic development. The lack of education during the colonial era is one of the key reasons why Africa was held back for more than a century. When Mozambique finally gained independence from Portugal in 1975, the country had just a handful of African high-school graduates.

Britain's Imperial rule left a lot of violence and deranged societies, but it also left a little bit of infrastructure and some institutions of lasting value, such as the courts. I wouldn't exaggerate this impact though, because I think a country needs colonial rule to have improved institutions. Reform can occur without imperial rule from the outside (as happened in Japan, for example). For example, a poor, institutionally laggard country could say: "Thank you. Why don't you perhaps send us an academic to give us a lecture, rather than sending your troops to conquer us?", and I think that the institutional reform could emerge just fine.

After World War II, Britain's imperial powers passed to the United States. The U.S. did not rule directly as empire, but rather indirectly by imposing friendly governments where it could. CIA-led regime change, for example, became a fixture of U.S. foreign policy, with U.S. leaders believing that they had the "right" and practical power to topple regimes they did not like. This habit of U.S.-led regime change has typically ended very badly for both the U.S. and the target country, as in Vietnam or more recently in Afghanistan, Iraq, Libya, and Syria. Figure 10 is a map of America's current military presence overseas. The United States has overseas bases in about seventy countries in the world, a classic case of imperial overstretch.

\section{The Era of Convergence, 1950-Present}

Let's move on to brighter news, shown in Fig. 11, which depicts one aspect of the current information revolution. Moore's Law describes the remarkable increase in computing power,

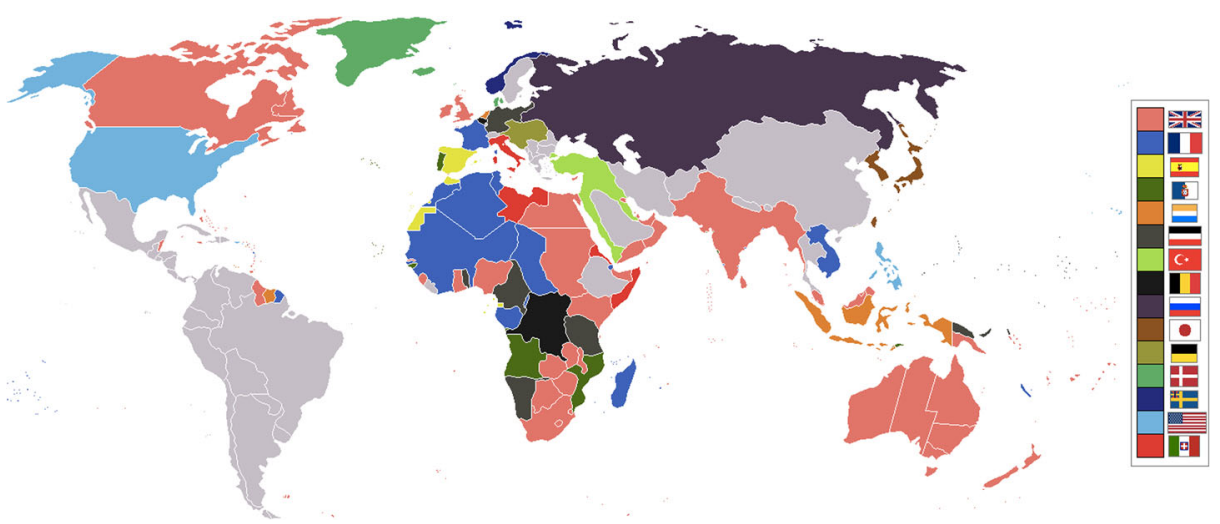

Fig. 9 Map of world empires in 1914 


\section{US military presence overseas}

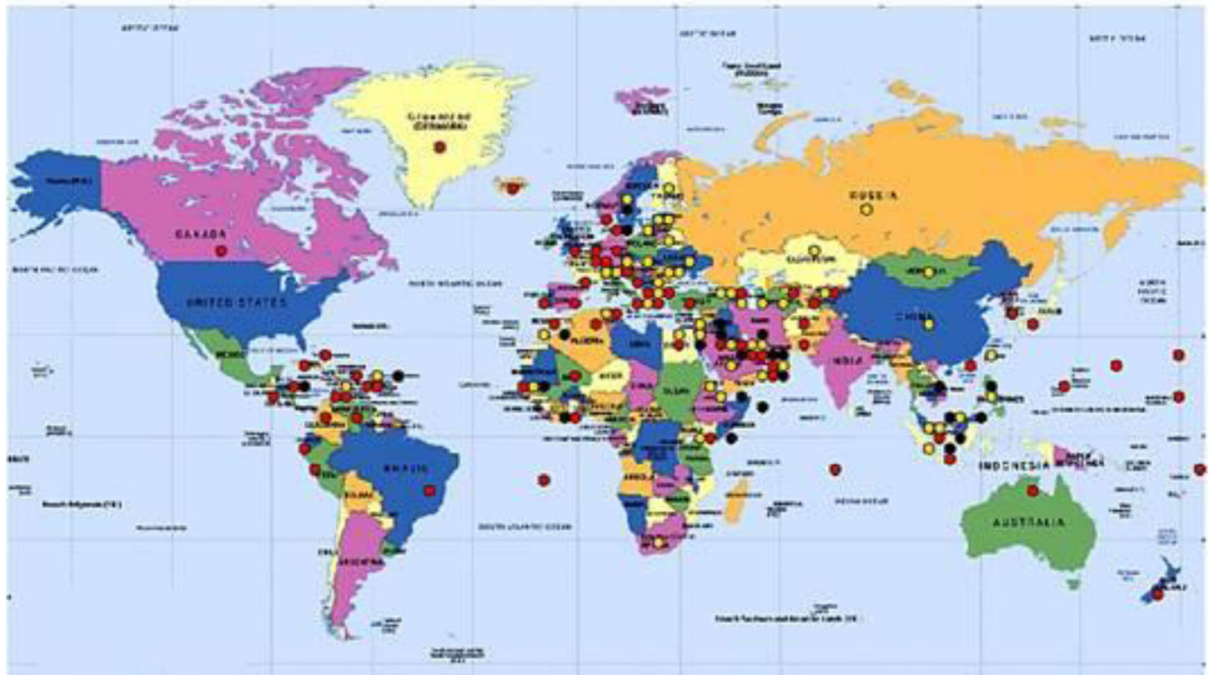

\section{Country with US Military Base}

\section{Country with Access Arrangement}

\section{Country with other Forms \\ of Military Cooperation}

Fig. 10 US military presence overseas

expressed roughly as the doubling of transistors per micro-processer every 1-2 years. Intel went from 2300 transistors on its first microprocessor in 1971 to 5 billion as of 2012. This remarkable progress in the capacity to store, process, and transmit data made the information revolution possible. It made possible a world with 7 billion mobile phone subscribers (Fig. 12). It will lead to near-universal broadband connectivity within the next decade everywhere, even including in poor rural villages of Africa possible.

For the first 150 years of the Industrial Revolution the world had essentially two core centers of innovation: Western Europe, especially Germany and the United Kingdom; and the United States, especially the East Coast of the United States. After World War II, the information age gave birth to Silicon Valley, with Berkeley, Stanford, the semiconductor

Fig. 11 The information age: transistor count on Intel microprocessors

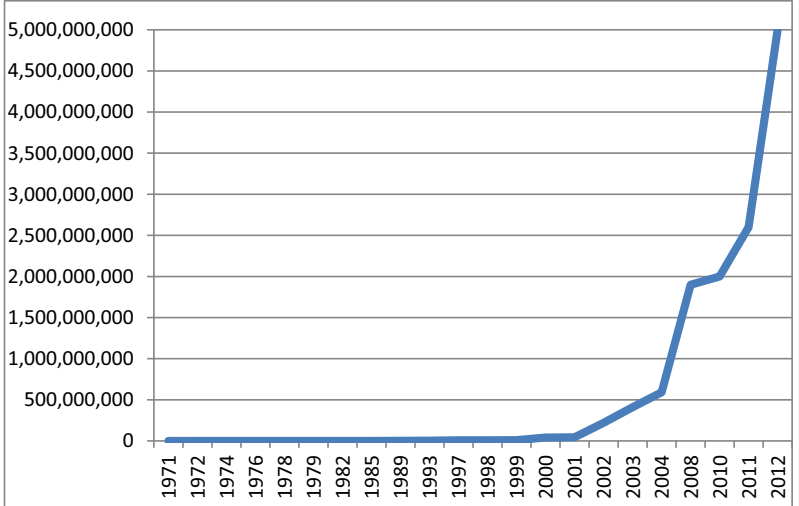




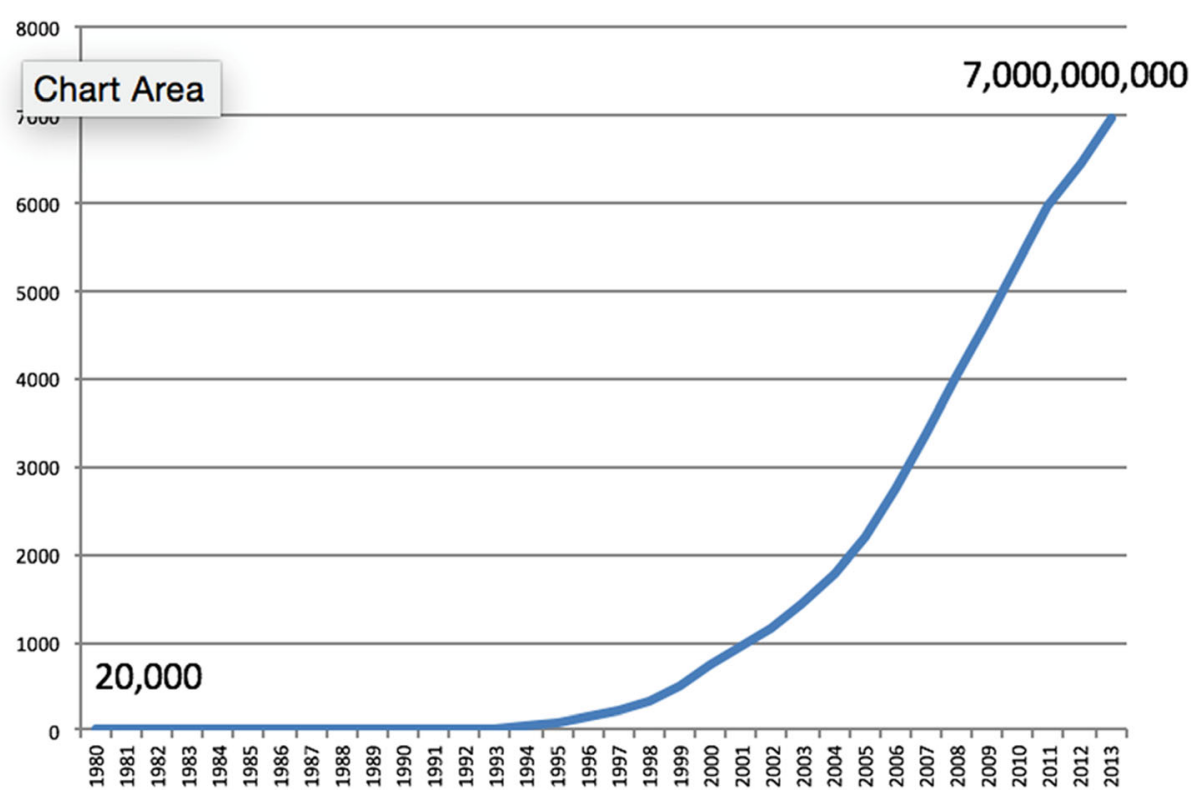

Fig. 12 Mobile subscribers worldwide, 1990-2013

revolution and the military complexes of California, giving rise to another zone of innovation. This made three major zones of innovation.

Now there is a fourth major zone of innovation: Northeast Asia, including China, Japan, and Korea, shown in Fig. 13. Of course, if I had more than an hour, I'd be a little more nuanced on this point. Japan's industrialization began in 1868 and it was the only industrializing country of Asia for a century. Korea and Taiwan began to industrialize in the 1960s. China, with its outward orientation, after 1978 began the most rapid catching-up process in economic

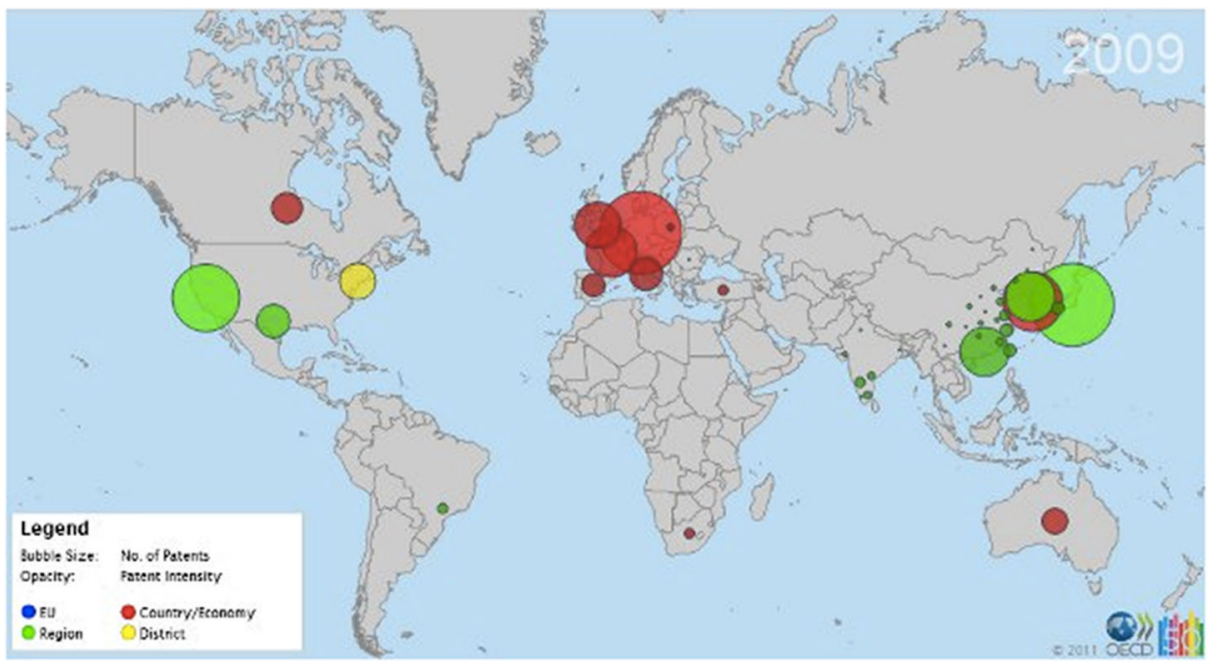

Fig. 13 Patent hotspots worldwide, OECD data, 2009 
history. Thus, Japan has been at the cutting-edge of technology for decades, while China has only recently arrived, but has arrived with enormous and exciting capacity for the future.

Remarkably, Korea, Japan, and China taken together are producing more patents in total than Europe or the United States. Of course, the three East Asian powerhouses don't view themselves yet as one integrated entity; in fact, there is currently a geopolitical divide, between the U.S. allies Japan and Korea on one side and China on the other side. Yet my guess is that this divide will prove to be a transitory phenomenon and that a fairly unified Northeast Asian economic community will be core a feature of the 21 st century. It may indeed become the center of gravity of the world economy in 30 or 40 years.

The catch-up of Northeast Asia is really something new because the North Atlantic has dominated the world economy for at least two centuries, and the West has been in the ascendancy for 500 years. I think that the North-Atlantic-led world economy is gradually being replaced by a multipolar world in which East Asia, and potentially Southern Asia, because major global centers of power, innovation, and dynamism.

Now, one very important fact to note is that in the course of this convergent growth after 1950 , global poverty has fallen sharply, even decisively one can say. China had an estimated 60\% rate of extreme poverty in 1978 when Deng Xiaoping came to power. China's poverty rate today, by the standard of "extreme poverty" as calculated by the World Bank, is probably down to about $5 \%$. Never before has such a large nation escaped from poverty so fast. It took Europe two centuries. It took China basically thirty-five years. This is a result of rapid catch-up growth, made possible by the information revolution and the deepening of globalization. It is a huge plus for human well-being. The decline of extreme poverty in our time, from around $37 \%$ of all households in 1990 to around $10 \%$ as of 2015 , has been a major contributor to improved human well-being (Fig. 14).

The rapid decline of global poverty has indeed produced so much hope that the 193 member states of the UN adopted the Sustainable Development Goals (SDGs) in September 2015. SDG 1 calls on the world to end extreme poverty — end it completely — by 2030. The UN member states are not radicals. They are sober-headed. The fact that these governments could envision the end of extreme poverty by 2030 means that it is feasible, though it is by no means guaranteed.

Fig. 14 Global poverty rate vs. number of poor 1990-2015 (Cruz et al. 2015)

\section{Projections show that the global poverty rate may have fallen to single digits in 2015. Yet, the number of poor remains high.}

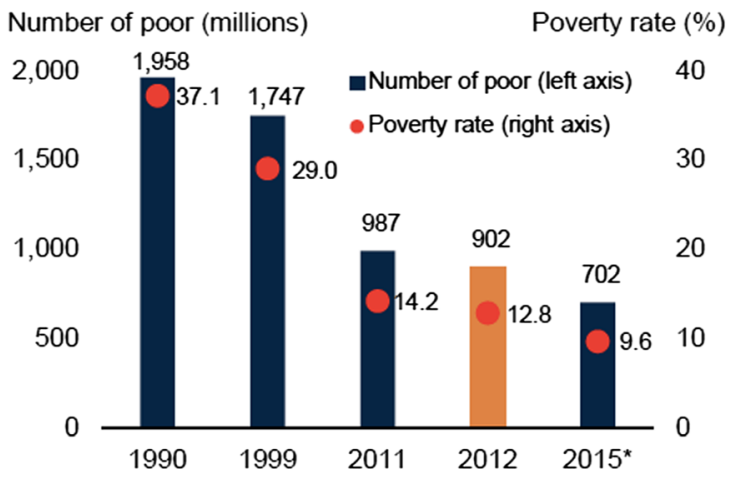

Note: Based on the $\$ 1.90$ poverty line and 2011 PPP. * is forecast 
The age of convergence since 1950, and especially the rise of northeast Asia, has produced a fundamental new phase of geopolitics based on a fundamental new phase of geo-economics. As we see in Fig. 15, the shares of the world output produced by Europe and the U.S. are in gradual decline, while the share of world output produced by Northeast Asia is rising. Indeed, the composite area of China-Japan-Korea is now far larger economically than either the European Union or the United States. We should of course remember that in per capita terms, China remains far behind the leaders, roughly one fourth of the US GDP per capita.

What then are the main lessons of this era of convergence? First, the rise of Northeast Asia is ending several centuries in which the North Atlantic countries have been ascendant (15001800) and dominant (1800-2000). Second, the end of extreme poverty in northeast Asia presages the end of extreme poverty globally. East Asia provides an important example and role model for the countries of South Asia and sub-Saharan Africa on how to eliminate extreme poverty.

Third, global-scale technological systems have played a central role, perhaps the central role, in global convergence. We live in a world of global-scale tehno-economic systems. In a few hours, when I fly home from Germany, I will get on a plane made by one of two producers, Airbus or Boeing. The pilots will fly the jet home using globally agreed and supervised protocols and technologies. As soon as I land, my mobile phone will immediately restore connectivity to the Internet, as it does all over the world. We do not speak about "local knowledge" in civil aviation, air traffic control, IP protocols, or 4G telecoms. These are all global systems, built for globalscale high performance, and we should be grateful for that. The once-laggard countries now leapfrogging economic development are achieving success by tapping into these global systems.

I emphasize this point because it is sometimes overlooked or hidden from view. Many of today's romantic thinkers, who are unhappy with the downsides of modern technologies, pine away for a simpler world. Yet there is no way that today's crowded planet of 7.5 billion people could feed itself, stay safe from epidemic diseases, obtain fresh water daily, and escape from extreme poverty, other than by plugging into sophisticated global systems of energy, water, communications, transport, and information.

Fig. 15 Shifting geo-economics: shares of World GDP

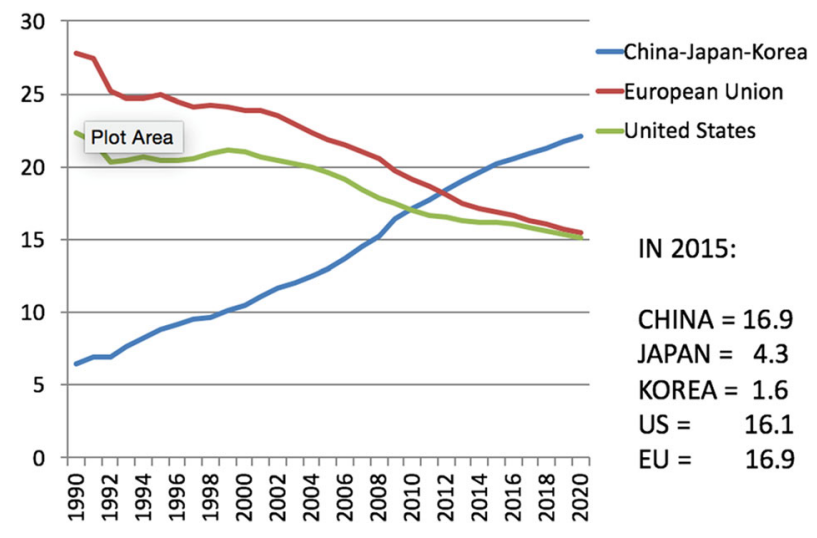


So, we need a sophisticated globalization and a technology-based globalization, but we also need a decency-based and environmentally sustainable globalization. That brings us to our generation's grand challenge: sustainable development.

\section{The New Globalization (Present-2100)}

The world needs a new globalization that is not only dynamic in terms of economic growth, but also fair in terms of the sharing of prosperity, and sustainable in terms of environmental impacts. This triumvirate of economic, social, and environmental objectives has an official name adopted by the 193 UN member states: sustainable development.

We are currently far off course to achieving sustainable development. Consider my own country, the United States. Since 1981, US public policy has been reckless, greedy, and corrupted, from the moment that the newly elected president Ronald Reagan declared, "The solution to our problems is not government; government is the problem." This idea unleashed an era of greed and irresponsibility that has dramatically exacerbated income inequality and dramatically intensified the damage to the natural environment, especially through humaninduced global warming.

Our generation's challenge is to mobilize our knowledge, expertise, goodwill, and moral vision into a transformation of the global economy so that it is not only productive, but also fair and sustainable. The so-called planetary boundaries (shown in Fig. 16) are the right starting point for incorporating the environment into our economic planning. We need to recognize that humanity must operate within safe ecological limits regarding climate change, water use, land use, pollution, and other threats to the planet.

My suggestion for all of us is the following. We had a little miracle last year. On September 25, 2015, the 193 Member States of the United Nations adopted a shared framework of Sustainable Development, described by the 17 Sustainable Development Goals for the year 2030 (Fig. 17). A few weeks after that, on December 12, the UN member states unanimously adopted the Paris Climate Agreement.

For the first time, we have a globally agreed framework for globalization. This framework can serve as the basis for actions to ensure that globalization is productive, fair, and sustainable. It can serve as a basis for engagement of the business sector, the universities, the politicians, civil society, the religious leaders, and other key groups in our society. I believe there is a phenomenal value to having a globally agreed framework. In dozens of countries around the world there is already an active effort to put the SDGs into practice.

I urge the wonderful Humanistic Management Network to embrace the Sustainable Development Goals as a framework for teaching, training, and business management, one that can help to infuse ethical practices into individual businesses and the global economy. What I am hoping is that we can turn the SDGs into real life, in politics, the platforms of political parties, the agendas of universities, and the behaviors and missions of businesses.

I can tell you, based on my 16 years advising the Secretary General of the United Nations, that implementing globally agreed goals is not an easy thing. But, it is our challenge now, and it is urgent that we succeed. What are the right modes for success?

The SDGs are the right starting point, because they give us a direction, a telos (end goal). Aristotle, yes, had it right 2500 years ago. He invented political science to solve the problem of achieving the end-goal of human happiness (eudaimonia) through the right kinds of politics. We need to cultivate the virtues and ethics that will promote sustainable development. 


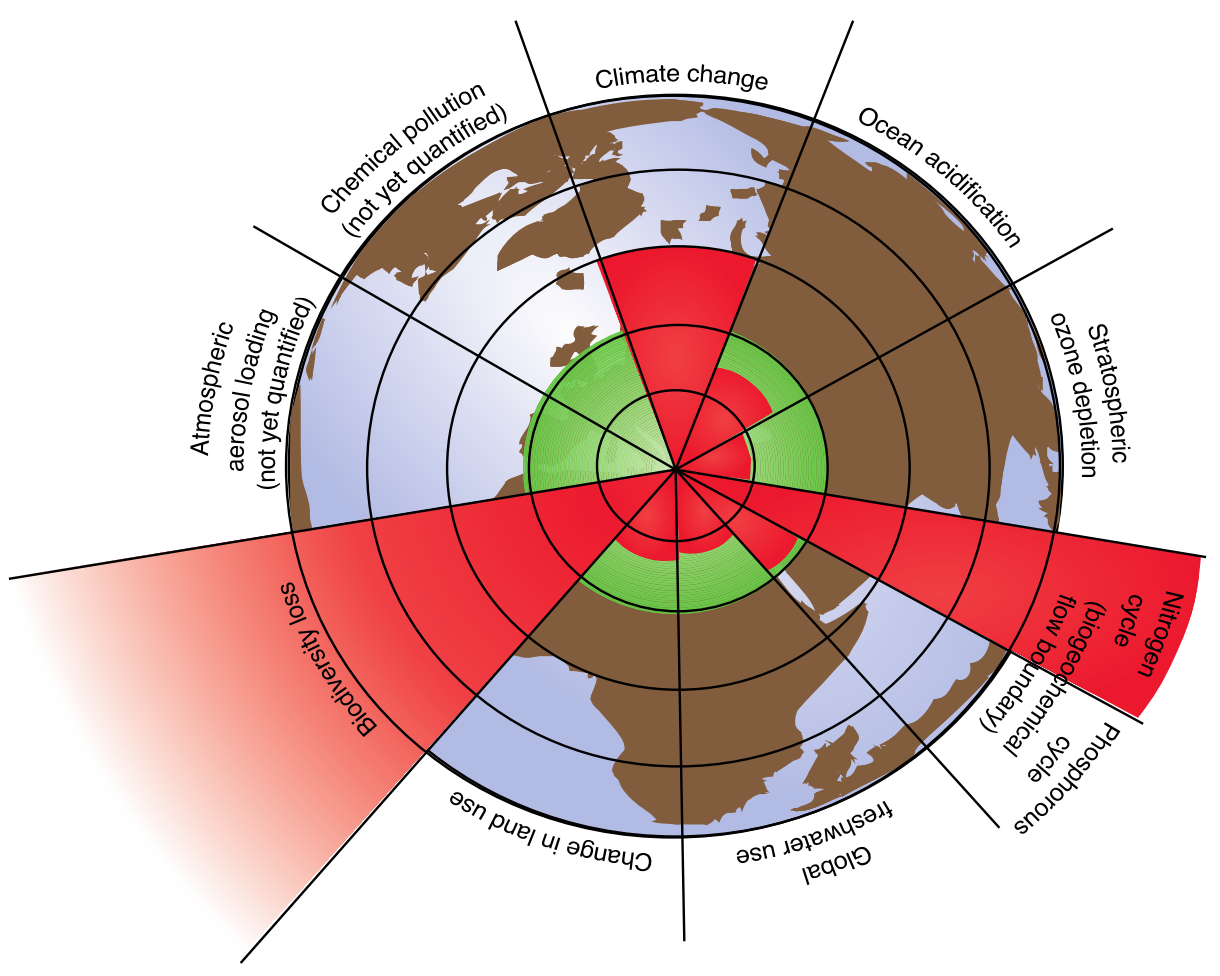

\section{Source: Rockström et al 2009}

Fig. 16 Planetary boundaries. Source: Rockström et al. 2009

We need to pay special attention to empowering the disempowered. The message of the Beatitudes, that "the poor shall come first" is at the core of social justice.

And, of course, we need expertise mobilized through active deliberation and fearless, unbiased analysis that universities are best at mobilizing.

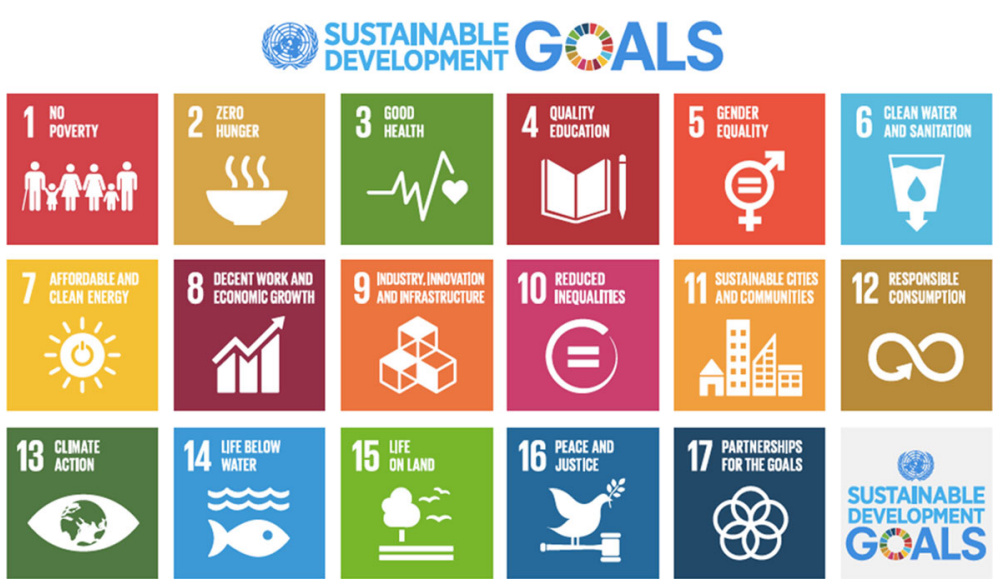

Fig. 17 The 17 Sustainable Development Goals 
All of this is to say we have a very, very large agenda to ensure that the next era of globalization truly serves the human good. Yet we have vast knowledge, both technical and ethical, many tools at our disposal, and all the reasons in the world to work together to succeed.

\section{References}

Cruz, M., J. Foster, B. Quillin, and P. Schellekens. 2015. Ending extreme poverty and sharing prosperity: progress and policies? The World Bank Group: Development Economics. Policy Research Note 2.

Rockstrom, J., W. Steffen, K. Noone, A. Persson, F. S. Chapin, III, E. Lambin, T. M. Lenton, M. Scheffer, C. Folke, H. Schellnhuber, B. Nykvist, C. A. De Wit, T. Hughes, S. van der Leeuw, H. Rodhe, S. Sorlin, P. K. Snyder, R. Costanza, U. Svedin, M. Falkenmark, L. Karlberg, R. W. Corell, V. J. Fabry, J. Hansen, B. Walker, D. Liverman, K. Richardson, P. Crutzen, and J. Foley. 2009. Planetary boundaries: exploring the safe operating space for humanity. Ecology and Society 14(2):32. [online] URL: http://www.ecologyandsociety.org/vol14/iss2/art32/. 